\title{
Improvement of Original Soil with Addition of Variation of Embankment Based on CBR (California Bearing Ratio) Value
}

\author{
Ibrahim Ibrahim ${ }^{1}$ Andi Herius ${ }^{1}$ Nadra Mutiara Sari ${ }^{1, *}$ \\ M Aidil Iskandarsyah² M Okta Fathur Rahman²
}

\author{
${ }^{1}$ Lecturer of Civil Engineering Sriwijaya State Polytechnic \\ ${ }^{2}$ Student of D-1II Civil Engineering Study Program Sriwijaya State Polytechnic \\ *Corresponding author. Email: nadra.mutiara.sari@polsri.ac.id
}

\begin{abstract}
Soil is the most widely used material in the construction of a construction. In order for the soil to carry the construction load on it, an improvement in the structure and density of the soil itself is needed. This is in accordance with the technical requirement that the soil must be hard. If the soil does not meet the requirements, it is necessary to stabilize it by adding embankment soil as in this study which stabilized clay soil with variations of $50 \%$ and $75 \%$ addition of selected embankment soil. Clay samples were taken in the Keramasan area. The test was carried out in the laboratory of the Department of Civil Engineering, State Polytechnic of Sriwjaya to determine the Comparison of CBR (California Bearing Ratio). The results showed that the original soil sample had a moisture content of $36.15 \%$, a specific gravity of 2.55 , a liquid limit of $65,65 \%$, plasticity index $31.36 \%$ and CBR $9.00 \%$. Based on the USCS Classification, the soil sample belongs to the $\mathrm{CH}$ type, which is clay with a moderate to poor rating. From the results of soil testing that has been stabilized, the optimal water content is $31 \%$, specific gravity is 2.60, liquid limit is $54.04 \%$, plasticity index (IP) is $24.70 \%$ and CBR 11.85 (addition of $50 \%$ of selected embankment soil). ). While the addition of $75 \%$ of the selected embankment soil, obtained the optimum moisture content of $25.1 \%$, specific gravity 2.60 , liquid limit $36.61 \%$, IP $13.19 \%$ and CBR $12.02 \%$. It can be concluded that the addition of $75 \%$ embankment soil gets a higher CBR value than the addition of $50 \%$ of embankment soil and original soil (without addition).
\end{abstract}

Keywords: clay soil, selected embankment soil, CBR

\section{INTRODUCTION}

In a construction, soil is the basic part that can bear the load of the structure above it. There areThere are many types of soil in Indonesia, especially in South Sumatra, but not all types of soil have a good bearing capacity as the foundation of a building. One type of soil in South Sumatra is clay. Clay soil is a type of finegrained soil that is strongly influenced by water content and has quite complex properties. If the content is more or less, then the carrying capacity of the soil will be low, and vice versa [1].

This creates problems for urban land, where the increase in demand for land is uncontrollable which causes land prices to also increase. So that the quality of the soil remains in good condition and can withstand the load of the structure above it, a stabilization of the soil is needed [2].
In Unified system, the soil is classified as coarsegrained soil (gravel and sand) if less than $50 \%$ passes the number 200 sieve, and as fine-grained soil (silt/clay) if more than $50 \%$ passes the 200 sieve.

The AASHTO classification system divides the soil into into 8 groups, A-1 to A-8 including subgroups. Soils in each group are evaluated against the group index which is calculated by empirical formulas. The group index (GI) was used to further evaluate the soils within the group. [3]

Index plasticity (PI) is the difference between the liquid limit and the plastic limit. . If the soil has a high PI, then the soil contains a lot of clay grains. If the PI is low, such as silt, a slight reduction in the water content results in the soil becoming dry. [4] 
Table 1. Spesifik Grafity

\begin{tabular}{|l|c|}
\hline \multicolumn{1}{|c|}{ Types of Soil } & Specific gravity \\
\hline Gravel & $2,65-2,68$ \\
\hline Sand & $2,65-2,68$ \\
\hline inorganic silt & $2,62-2,68$ \\
\hline Organic clay & $2,58-2,65$ \\
\hline Anorganic clay & $2,68-2,75$ \\
\hline humus & 1,37 \\
\hline clay & $1,25-1,80$ \\
\hline
\end{tabular}

The specific gravity of the soil is the ratio between the weight of the soil grains and the volume of solid soil or the weight of water with the same content as the content of the soil at a certain temperature.

CBR indicates the relative value of soil strength, the higher the density of the soil, the higher the CBR value. However, it does not mean that the subgrade should be compacted with low water content in order to get a high CBR value, because the water content may not be constant under these conditions. There are several ways that have been done by previous researchers to maintain/improve soil quality.

Improving the quality of clay can be done with a mixture of beach sand where the higher CBR value is obtained [5]. The addition of other materials such as plastic is also sure to increase the CBR value of the soil. In addition, fly ash can also improve the quality of the CBR value of the soil [6].

Based on several previous researchers, it is necessary for further research by using the same material, namely the soil itself. The soil used in this study is soil originating from the Keramasan area, South Sumatra Province. This land includes selected and quality land. The addition of the original soil is expected to increase the CBR value of the soil. The CBR examination aims to determine the CBR price of soil compacted in the laboratory at a certain water content

\section{RESEARCH METHOD}

\subsection{Genies and Research Locations}

This research was carried out using experimental research methods on all types of materials needed for this research. The research materials used were embankment soil and original soil. Soil samples taken were disturbed soil in the Keramasan District, Banyu Asin Regency, South Sumatra. Soil samples were taken at several sampling locations at a depth of approximately $10 \mathrm{~cm}$.

\subsection{Research Stages}

The stages of the research can be seen in the following diagram

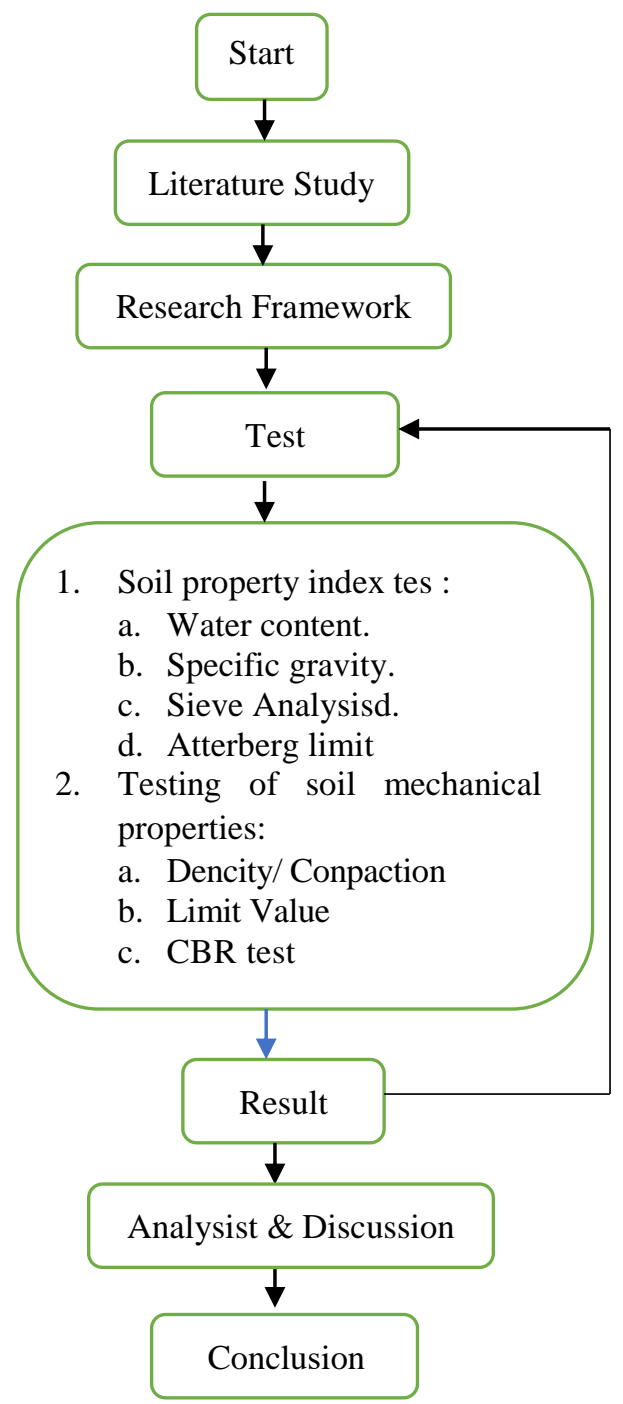

Figure 1. Research Flowchart

\section{FINDING}

\subsection{Real Soil Test}

Before testing of mixed soil is carried out, first testing the original soil sample. Data from the results of testing the original soil sample can be seen in Table 2. 
Table 2. Original Soil Test Data

\begin{tabular}{|l|l|l|l|}
\hline No & $\begin{array}{l}\text { type of soil \& } \\
\text { additives }\end{array}$ & $\begin{array}{l}\text { maximum } \\
\text { dry weight } \\
\text { gr/cm3 }\end{array}$ & $\begin{array}{l}\text { optimum } \\
\text { water } \\
\text { content (\%) }\end{array}$ \\
\hline & red clay & 1,46 & 30 \\
\hline & Black clay & 1.33 & 35 \\
\hline & $\begin{array}{l}\text { Original soil 2\% } \\
\text { + red clay 75\% }\end{array}$ & 1,51 & 25,1 \\
\hline & $\begin{array}{l}\text { Red clay 50\% + } \\
\text { black clay 50\% }\end{array}$ & 1,36 & 31 \\
\hline
\end{tabular}

\subsection{Soil Mechanical Properties Testing}

\subsubsection{Compaction (Standard Compaction)}

Result of compaction test with variations of petrasoil and clay added materials can be seen in Table 3

Table 3. Standard Compaction Test Results

\begin{tabular}{|l|c|c|}
\hline Index Properties & Result & unit \\
\hline Specific Gravity (GS) & 2,55 & - \\
\hline Passing the filter No. $10(2.00 \mathrm{~mm})$ & 100 & $\%$ \\
\hline Passing the filter No. $40(0.425 \mathrm{~mm})$ & 100 & $\%$ \\
\hline Passing the filter No. $200(0.075 \mathrm{~mm})$ & 98,54 & $\%$ \\
\hline Liquid Limit $(L L)$ & 65,65 & $\%$ \\
\hline Plastis Limit $(P L)$ & 34,29 & $\%$ \\
\hline Indeks Plastisitas (IP) & 31,36 & $\%$ \\
\hline Soil Clasification(USCS) & $\mathrm{CH}$ & - \\
\hline Wopt & 35,00 & $\%$ \\
\hline fdmak & 1,33 & $\mathrm{gr} / \mathrm{cm}^{3}$ \\
\hline
\end{tabular}

The water content and volume of dry soil from the compaction will be used as calculations to determine the water content and weight soil content in the next test, namely the CBR (California Bearing Ratio) test

\subsubsection{Laboratory CBR (California Bearing Ratio) Testing}

This test was carried out under CBR conditions without soaking (unsoaked) and curing for 1 day. The variation used in the CBR test is the same as the mixed variation in the standard compaction test. The results of the unsoaked CBR test with variations can be seen in Table 4
Table 4. CBR Test Results

\begin{tabular}{|c|l|c|}
\hline No & \multicolumn{1}{|c|}{$\begin{array}{c}\text { Type of soil \& } \\
\text { additives }\end{array}$} & $\begin{array}{c}\text { CBR } \\
\text { Average (\%) }\end{array}$ \\
\hline 1 & Red clay & 12,41 \\
\hline 2 & Black clay & 9,00 \\
\hline 3 & Original soil 25\% + red clay 75\% & 12,02 \\
\hline 4 & Red clay 50\% + black clay 50\% & 11,85 \\
\hline
\end{tabular}

\subsection{Consistency Limits Test}

Test for Consistency limits include the liquid limit test (LL), plastic limit (PL), and plastic index (PL). The effect of adding 50\%+ $50 \%$ mixture percentage on the consistency values is shown in the figure 2 and mix percentage $50 \%$ $+50 \%$ on figure 3 .

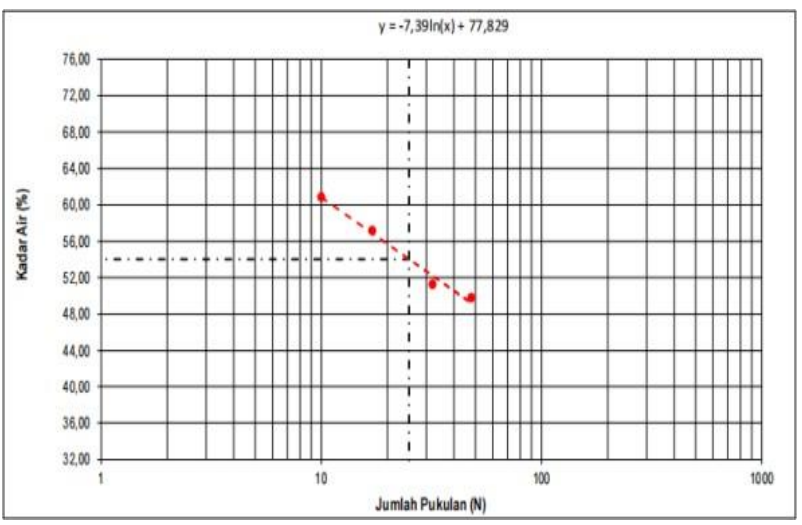

Figure 2. Relationship of Additive PercentageDith Consistency Limit Value

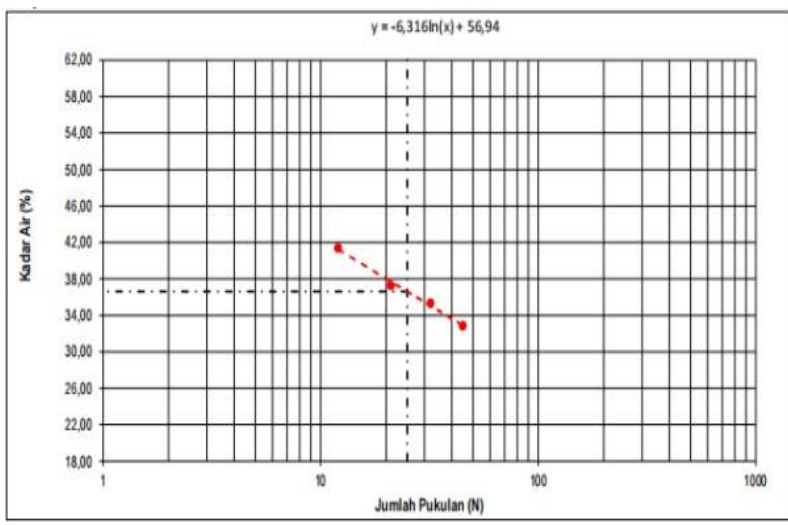

Figure 3. Graph The Relationship between the Percentage of Added Materials and the Consistency Limit Value

Based onn graph, the results of testing the consistency limit for the original soil, the liquid limit value (LL) obtained is $65.65 \%$. After adding the LL red clay, it becomes $54.04 \%(50 \%)$ and $36.61 \%(75 \%)$ 


\subsection{Compaction Test}

Examiner Compaction is carried out to determine the optimum moisture content and maximum density in the soil. The results of standard compaction can be seen in the following graph

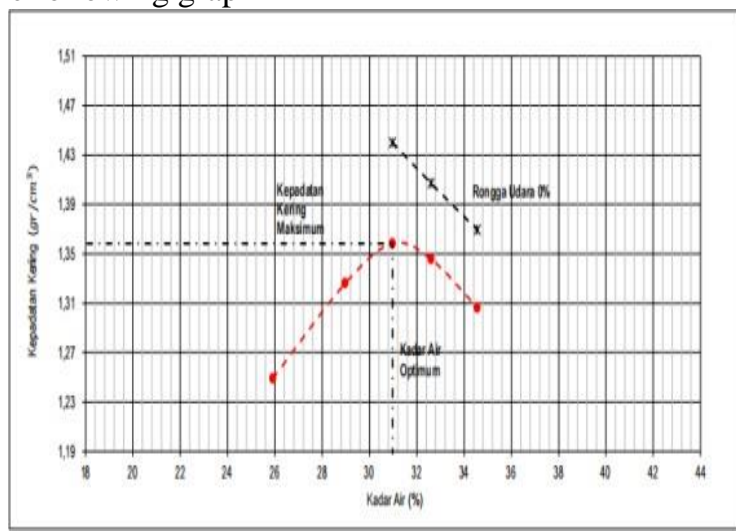

Figure 4. Graph of 50\% Optimum Moisture Content

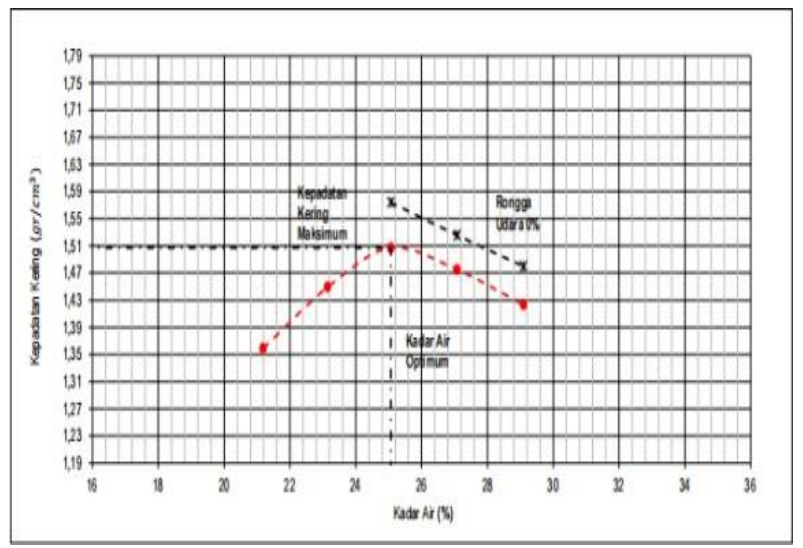

Figure 5. Graph of 75\% Optimum Moisture Content

Based onn graph 4.3 and graph 4.4 , the optimum water content value for the original soil was obtained at $36.15 \%$. With the addition of $50 \%$ clay, the optimum water content value decreased from the original soil optimum water content value to $31.00 \%$ (50\%) and $25.06 \%(75)$.

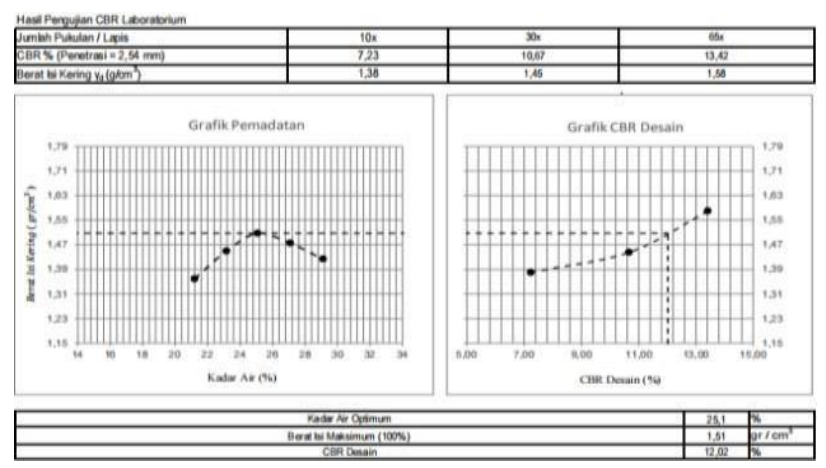

Figure 6. CBR Graph of Lab Testing
From Laboratory test results obtained optimal moisture content of $31 \%$, maximum density of 1.36 $\mathrm{gr} / \mathrm{cm}^{3}$ and design CBR of $11.85 \%$ (for the addition of $50 \%$ of embankment soil) and optimum moisture content of $25.1 \%$, maximum bulk weight $1.56 \mathrm{gr} / \mathrm{cm}^{3}$ and $12.02 \%$ design CBR.Detail Result ini CBR test can be seen ini Table 5 .

Table 5.Detail CBR Test results

\begin{tabular}{|l|l|l|l|l|}
\hline No & Material & $\begin{array}{l}\text { Limit } \\
\text { Liquid }\end{array}$ & $\begin{array}{l}\text { Water } \\
\text { content }\end{array}$ & CBR \\
\hline 1 & Original Siol & $65,65 \%$, & $36,15 \%$ & $9,0 \%$ \\
\hline 2 & Added $50 \%$ & $54.04 \%$ & $31.00 \%$ & $11,85 \%$ \\
\hline 3 & Added $75 \%$ & $36,61 \%$ & $25,06 \%$ & $12,02 \%$ \\
\hline
\end{tabular}

\subsection{Soil Behavior Due to Addition Clay}

From the results above, it can be concluded that the behavior of the soil due to the addition of clay in the table below:

Table 6. Soil Behavior Due to Addition clay

\begin{tabular}{|c|l|l|}
\hline No. & Overview & \multicolumn{1}{|c|}{ Behaviour } \\
\hline 1. & $\begin{array}{l}\text { Atterberg } \\
\text { Limit }\end{array}$ & $\begin{array}{l}\text { On the addition of the clay } \\
\text { mixture, the liquid limit value } \\
\text { decreased. The higher the } \\
\text { percentage of clay added, the } \\
\text { lower the liquid limit value. }\end{array}$ \\
\hline 2. & $\begin{array}{l}\text { Standard } \\
\text { Compaction }\end{array}$ & $\begin{array}{l}\text { At the addition of 50\% clay } \\
\text { mixture, the value of the } \\
\text { optimum water content tends } \\
\text { to increase. }\end{array}$ \\
\hline 3. & $\begin{array}{l}\text { CBR } \\
\text { Unsoaked }\end{array}$ & $\begin{array}{l}\text { n the addition of clay mixture } \\
50 \%, \text { unsoaked CBR value } \\
\text { tends to decrease. }\end{array}$ \\
\hline
\end{tabular}

\section{CONCLUSIONS}

The results of the tests carried out were then analyzed and obtained the results are:

1. Based on the USCS Classification, the soil sample belongs to the $\mathrm{CH}$ type, which is clay for road with a medium to good rating

2. The addition of $75 \%$ embankment soil gets a higher CBR value than the addition of $50 \%$ of embankment soil and original soil (without addition).CBR test, Just litle bit increase betwen $50 \%$ with $75 \%$ and not be effect. 


\section{ACKNOWLEDGMENTS}

We thanks to Sriwijaya Polytechnic for the opportunity to conduct for this study.

\section{REFERENCES}

[1] Herman Darmawan, M. (t. yr.). ATTERBERG Limits Test. Soil Mechanics.

[2] Indonesia, SN (2011). How to Test CBR (California Bearing Ratio) Jakarta Field: National Standardization Agency.

[3] Herman Darmawan, M. (t. yr.). Soil Specific Gravity Test. Soil Mechanics.

[4] Hardiyatmo, H. (2012). Soil Mechanics I. Jakarta: PT. Main Library Gramedia.
[5] Mada, UG (t.yr.). Field Soil Density Inspection. Civil Engineering Soil Mechanics Laboratory.

[6] National, BS (t.yr.). METHOD OF TESTING SOIL WATER LEVELS SNI 03-1965-1990. In SN Indonesia. Jakarta

[7] Craig, B. (1991). Soil Mechanics. Jakarta: Erlangga

[8] Das, BM (1995). Soil Mechanics (Principles of Geotechnical Engineering) Volume I. Jakarta: Erlangga.

[9] Mada, UG (t.yr.). Field Soil Density Inspection. Civil Engineering Soil Mechanics Laboratory.

[10] Indonesia, SN (t.yr.). Method of testing the plastic limit of the soil. Jakarta: Research and Development Agency of the Ministry of Public Works. 